УДК 342.25, 342.59

DOI: https:/ / doi.org/10.47567/ bomivit.1-4.2020.05

Р. М. Хван, здобувач Інституту законодавства Верховної Ради України

Ruslan.khvan@i.ua

ORCID: 0000-0002-5053-6343

\title{
СУБ'СКТНИЙ СКЛАД МУНІЦИПАЛЬНОЇ ПРАВОВОЇ ПОЛІТИКИ УКРАЇНИ
}

\author{
R. M. Khvan, \\ Applicant at the Legislation Institute of \\ The Verkhovna Rada of Ukraine \\ Ruslan.khvan@i.ua \\ ORCID: 0000-0002-5053-6343
}

\section{SUBJECT COMPOSITION OF THE MUNICIPAL LEGAL POLICY OF UKRAINE}

У статті досліджується сутність муніципальної правової політики як системи стратегічного управління самоврядною діяльністю. Визначено, що діяльність добровільних об'єднань органів місцевого самоврядування як суб'єктів державної муніципальної політики є одним із проявів та форм організаційної самостійності органів місцевого самоврядування у реалізації парадигми регіонального інтересу. Ця незалежність гарантується Конституцією України, Європейською хартією місцевого самоврядування, законами України "Про місцеве самоврядування в Україні" та "Про асоціації органів місцевого самоврядування". Досліджено сутність і особливості суб'єктів місцевого самоврядування, окремі їхні категорії, закономірності й тенденції розвитку. Підкреслюється, що територіальні громади безпосередньо чи опосередковано, їх органи влади, неурядові організації реалізують свою правосуб'єктність як у межах держави, так і поза ії межами. Визначено,що територіальні громади наділені: правом формування відповідних органів через проведення виборів, загальних зборів громадян за місцем проживання; правом проведення місцевих референдумів, місцевих ініціатив, громадських слухань, індивідуальних і колективних звернень, громадських експертиз та обговорень, інших не заборонених конституцією форм місцевої демократії; правом управління місцевими бюджетами, рухомим і нерухомим майном комунальної власності; правом укладати міжнародні угоди профільної спрямованості тощо. Відзначено, що перехід до формування муніципальної правової політики вимагає кардинального перегляду всієї ідеології місцевого самоврядування, технологій управління, практики прийняття рішень та розподілу ресурсів. Визначено перспективи функціонування, удосконалення статусу суб' єктів місцевого самоврядування.

Ключові слова: муніципальна правова політика, місцеве самоврядування, 
державна політика, територіальні громади, суб'єкти, правосуб'єктність.

The article examines the essence of municipal legal policy as a system of strategic management of self-governing activities. It is determined that the activity of voluntary associations of local self-government bodies as subjects of state municipal policy is one of the manifestations and forms of organizational independence of local self-government bodies in the implementation of the paradigm of regional interest. This independence is guaranteed by the Constitution of Ukraine, the European Charter of Local SelfGovernment, the laws of Ukraine "On Local Self-Government in Ukraine" and "On Associations of Local Self-Government Bodies". The essence and peculiarities of local selfgovernment subjects, their separate categories, regularities and tendencies of development are investigated. It is emphasized that territorial communities directly or indirectly, their authorities, non-governmental organizations exercise their legal personality both within the state and abroad. It is determined that territorial communities are endowed with: the right to form relevant bodies through elections, general meetings of citizens at the place of residence; the right to hold local referendums, local initiatives, public hearings, individual and collective appeals, public examinations and discussions, other forms of local democracy not prohibited by the constitution; the right to manage local budgets, movable and immovable property of communal property; the right to conclude international agreements of profile orientation, etc. It is noted that the transition to the formation of municipal legal policy requires a radical overhaul of the entire ideology of local government, management technologies, decision-making practices and resource allocation. Prospects for the functioning and improvement of the status of local selfgovernment entities have been identified.

Key words: municipal legal policy, local self-government, state policy, territorial communities, subjects, legal personality.

Постановка проблеми. Сучасний етап розвитку України можна охарактеризувати як етап формування громадянського суспільства і побудови демократичної правової державності. Необхідною передумовою становлення громадянського суспільства $є$ розвиток інституту місцевого самоврядування, як найближчого безпосередньо до населення рівня публічної влади і публічного управління.

У історичній ретроспективі радянського народовладдя влада на місцях - на локальному і регіональному рівнях функціонування соціуму власне і не відрізнялася самостійністю, рішення завжди спускалися "згори", а відсутність неспроможних місцевих бюджетів - було яскравим доказом фінансової залежності територій. Але ж відповідно до Конституції України 1996 року місцеве самоврядування забезпечує самостійне вирішення населенням питань місцевого значення, структура органів місцевого самоврядування визначається населенням самостійно [1]. Отже, на сучасному етапі розвитку нашої держави реформування інституту місцевого самоврядування стало об' єктивною необхідністю.

Основною метою реформи місцевого самоврядування виступає завдання наблизити публічну владу не стільки до «міфічного» розуміння народу, скільки задіяти колективістський потенціал локальних територіальних спільнот територіальних громад для вирішення актуальних питань існування та функціонування населення відповідних територій держави. Отже, ухвалення 
профільного Закону про місцеве самоврядування в Україні від 21 травня 1997 року ознаменувало початок чергового етапу реформування місцевого самоврядування. Однак, в ході реформи місцевого самоврядування виникає безліч питань і проблем, пов'язаних з суб'єктним складом муніципальної правової політики України.

Аналіз останніх досліджень і публікацій. Муніципальна правова політика $є$ одним 3 різновидів та одним 3 найважливіших сегментів державної правової політики. Останній в даний час приділяється значна увага 3 контекстуалізацією питань трансформації соціуму i держави. Питання муніципальної правової політики багатогранне, оскільки пов' язане з різними вимірами та характеристиками розвитку систем (підсистем) публічної влади. Багатогранність, зокрема, пов'язана 3 регіоналізацією територій, новою державною регіональною політикою, адміністративно-територіальною реформою, а також з реформою муніципальною, що виступає наріжним камінням муніципальної правової політики.

Отже, ключовим елементом зазначених процесів $є$ місцеве самоврядування. Висвітлення цих та інших питань можна знайти в наукових працях багатьох вчених, зокрема М. Баймуратова, О. Батанова, В. Борденюка, П. Ворони, I. Дегтярьової, М. Корнієнка, В. Кравченко, М. Лахижи, В. Погорілка, Т. Сивак, та ін. Їхні дослідження порушують величезний спектр питань, які прямо чи опосередковано пов'язані 3 розвитком місцевого самоврядування та громадянського суспільства. Проте сьогодні існує нагальна потреба у вивченні муніципальної правової політики крізь призму дослідження ії суб'єктного складу. Це відбувається на тлі того, що питанням самої муніципальної-правової політики приділяється явно недостатньо уваги. Звідси, об'єктивується гостра необхідність саме на загальнотеоретичному рівні досліджувати такий різновид правової політики держави як муніципальна правова політику та її суб'єктний склад.

Невирішені раніше частини загальної проблеми. Питанням же муніципальної-правової політики приділяється явно недостатньо уваги. Звідси гостра необхідність саме на загальнотеоретичному рівні досліджувати такий різновид правової політики як муніципальної-правову політику та ії суб'єктний склад.

Мета статті полягає в загальнотеоретичному комплексному аналізі муніципальної-правової політики як особливого різновиду правової політики, дослідженні ії суб'єктного складу.

Виклад основного матеріалу. Для більш глибокого розуміння муніципальної правової політики необхідно зазначити, що це самостійний вид правової політики. Дійсно, муніципальна правова політика - це послідовна, стратегічно і телеологічно обгрунтована діяльність органів держави і місцевого самоврядування, що:

а) не суперечить правовій політиці держави Україна;

б) здійснюється в інтересах населення, що проживає на території конкретної територіальної спільноти - територіальної громади;

в) має за мету системне і комплексне вирішення нагальних питань місцевого розвитку в контекстуалізації його невпинності, оптимальності та сталості;

г) спрямована на оптимізацію муніципальної-правового регулювання.

Вважаємо, що характерологічні риси наведеного визначення містять і основні ознаки муніципальної правової політики та відрізняють іï від родової правової політики держави. Отже, муніципальну правову політику від правової політики держави в цілому відрізняють наступні риси: 
- по-перше, - у суб'єктній архітектоніці, що є достатньо складною і носить комплексний характер - ï основними діяльнісно-функціональними суб'єктами є органи місцевого самоврядування. Під органами місцевого самоврядування розуміються обрані безпосередньо населенням і (або) утворені представницьким органом територіальної громади органи, що наділені владними повноваженнями у вирішенні питань місцевого значення. Разом $з$ тим, одночасно, суб'єктами такої профільної політики, що фактично $\epsilon$ iї розробниками, організаторами, модернізаторами, органами, що ії легалізують і відповідним чином легітимізують через функціональну реалізацію, - виступають і інші органи публічної влади, зокрема вищого рівня - Парламент, Президент, Кабінет Міністрів. Бо саме вони, відповідно до своїх компетенційних повноважень розробляють стратегічні напрями муніципального реформування, приймають відповідні нормативно-правові акти в цій сфері, зокрема законодавчого характеру (Парламент) та приймають відповідні організаційні та організаційно-правові заходи з їх втілення в практику (Президент, Кабінет Міністрів). Крім того, активними суб'єктами-об'єктами муніципальної правової політики виступають саме жителі-члени територіальних громад, що, своєю чергою, і є первинними суб'єктами місцевого самоврядування. Можна виокремити ще суб'єктів муніципальної правової політики;

- по-друге, муніципальна правова політика - у субординаційному розумінні не повинна суперечити правовій політиці держави в цілому - по великому рахунку, вона повинна виступати іï органічною складовою частиною, що відповідає основоположним завданням і функціям становлення і розвитку демократичної правової держави, і в практичному розумінні складати відповідний «пазл», вбудовування якого в загальну систему координат державної політики буде здійснюватися безболісно, без суперечок і колізій, не порушуючи стратегічних настанов державності, що виникає, будується і трансформується;

- по-третє, муніципальна правова політика - у інтерсуб'єктивному розумінні повинна здійснюватися в інтересах населення, що проживає на відповідній території держави в межах відповідних адміністративно-територіальних одиниць (сіло /об'єднання декількох сіл/, селище, місто) чи асоційованих територій (район, область - навіть в контексті їх можливого реформування), тобто в інтересах жителівчленів територіальної громади за їх допомогою або за їх участі, причому разом 3 відповідними представницькими i виконавчими органами місцевого самоврядування;

- по-четверте, муніципальна-правова політика - у системологічному розумінні - це системна i комплексна, багатофакторна i багаторівнева діяльність уповноважених суб'єктів, що:

а) спрямована і скерована не тільки на оптимізацію державної муніципальноправової регламентації і регулювання, основними засобами якої $є$ норми права, а i локальної нормотворчості, що здійснюється належними їі суб'єктами через правові норми, що прийняті на рівні територіальних громад,

б) зазначені норми містяться в правових актах держави і органів місцевого самоврядування, і в підсумку нормопроєктної діяльності, вибудовують відповідні муніципально-правові відносини, що ілюструють відповідні «правила гри» суб'єктів місцевого самоврядування на локальному рівні існування i функціонування соціуму,

в) метою чого є здійснення передбачуваного, багато в чому формалізованого, 
обтяжливого відповідними організаційними і організаційно-правовими формами публічного управління в територіальній спільноті;

- по-п'яте, муніципальна правова політика - у праксеологічно-технологічному розумінні - має певну парадигмально-діяльнісну характеристику, що детермінує іiі структуру. Отже, тут спочатку виробляються правові ідеї стратегічного характеру, а потім відбувається процес їх реалізації або втілення в життя. Іншими словами, спочатку необхідним для уповноважених органів публічної влади (державної і самоврядної) розробити концептуальну основу муніципальної правової політики, забезпечити ії відповідним організаційним наповненням, нормативно-правовим змістом, ресурсним потенціалом, включаючи кадровий, технічний, технологічний, матеріально-фінансовий тощо), а потім приступити до ії реалізації;

- по-шосте, муніципальна правова політика - у аксіологічно-проспективному розумінні - це діяльність, що спрямована на певну перспективу. Однозначно, муніципальна правова політика, це свого роду планування діяльності органів місцевого самоврядування, звернене в майбутнє. На наш погляд, концепція муніципальної-правової політики повинна складатися на найближчі 5-10 років, так як тут можна прорахувати більш оптимально, що потрібно і необхідно зробити для розвитку місцевого самоврядування в державі, а також для розвитку територіальних громад, і як від запланованих заходів зміниться життя жителів-членів такої громади, а також рівень розвитку території на якій вона існує та функціонує;

- по-сьоме, муніципальна правова політика - у праксеологічному розумінні - це фактично локальна діяльність, що здійснюється на території конкретного муніципального об'єднання, тобто, перетворення, що відбуваються в ході реалізації реформи місцевого самоврядування, що зачіпають інтереси конкретної території.

Отже, наведені риси дозволяють стверджувати, що основна праксеологічна мета муніципальної правової політики - це забезпечення і послідовне підвищення рівня i якості життя жителів-членів територіальних громад та, у широкому розумінні, муніципальних утворень, особливо новостворених (маються на увазі об'єднані територіальні громади). Крім того, муніципальна правова політика переслідує і такі стратегічні телеологічні домінанти як:

- реформування системи місцевого самоврядування,

- набуття територіальною громадою реальної правосуб' єктності,

- формування належної компетенційної бази органів місцевого самоврядування через децентралізацію повноважень органів публічної влади,

- створення ефективних механізмів реалізації прав і свобод жителів-членів територіальних громад у сфері здійснення місцевого самоврядування через реалізацію ними свого конституційно-правового статусу,

- вдосконалення муніципальної правотворчості, через вдосконалення іiі технології і підвищення якості прийнятих муніципальних правових актів.

У вітчизняній практиці суб'єкти державної правової політики розуміються як вищі органи публічної влади. Фактично державна політика формується та легалізується законодавчою владою, реалізується (здійснюється) органами виконавчої влади та виконавчими органами місцевого самоврядування (з точки зору реалізації делегованих державою повноважень). Водночас, треба розуміти, що місцеве самоврядування та його суб'єкти (органи місцевого самоврядування, територіальна громада, органи самоорганізації, інституції громадянського суспільства тощо) можуть і повинні також формувати та реалізовувати власну 
політику на відповідній території, виходячи з їх інтересів та потреб - але під власну відповідальність і тільки в тому випадку, коли ці інтереси не суперечать інтересам держави і соціуму. Звідси, обгрунтовано вважаємо, що такий підхід вимагає кардинального перегляду всієї сучасної ідеології місцевого самоврядування, технологій управління, практики прийняття рішень та розподілу ресурсів. Отже, саме такі питання повинні вирішуватись в процесі муніципальної реформи, що зараз проходить в Україні.

Важливого значення в контексті ролі суб'єктів формування і реалізації настанов муніципальної правової політики на локальному рівні набувають органи виконавчої влади центрального, регіонального і локального (маючи на увазі введення в майбутньому інституту префектів) рівнів. Основні права органів виконавчої влади щодо адміністративного регулювання діяльності органів місцевого самоврядування визначаються Конституцією України, Законом України «Про місцеве самоврядування в Україні» та низкою інших нормативно-правових актів. Їх адміністративно-правовий статус випливає з їх компетенції у сфері управління суб'єктів юрисдикції, завдань, функцій, територіальних меж юрисдикції кожного окремого органу, повноважень з управління справами місцевого значення. У частині першій статті 24 Закону України "Про місцеве самоврядування в Україні" зазначено, що правовий статус місцевого самоврядування в Україні визначається Конституцією України, цим та іншими законами, які не повинні суперечити положенням цього Закону [1, ст. 24].

Особливості адміністративно-правового статусу органів місцевого самоврядування виявляються у їх відносинах з органами державної влади та їх посадовими особами, а також підприємствами, установами та організаціями різних форм власності. На рівні адміністративного регулювання державної муніципальної політики фундаментальним є принцип інституційної рівності, на якому мають базуватися відносини органів та посадових осіб державної влади 3 органами та посадовими особами місцевого самоврядування. Стаття 20 Закону України "Про місцеве самоврядування в Україні" [1] базується на тому ж принщипі, який закріплює повноваження органів державної влади щодо здійснення державного контролю за діяльністю органів та посадових осіб місцевого самоврядування. Держава зобов' язана здійснювати ці повноваження лише на підставі, в межах повноважень та у спосіб, передбачений Конституцією та законами України, щоб не втручатися у вирішення питань місцевого значення. Детальне регулювання власних та делегованих повноважень органів та посадових осіб місцевого самоврядування здійснюється главами 1-4 розділу II зазначеного Закону.

Систему місцевого самоврядування, визначають як сукупність суб'єктів і форм здійснення місцевого самоврядування, через які населення територіальної громади реалізує надані йому функції та повноваження [2, с. 133]. Аналіз національного законодавства дозволяє виокремити такі iï елементи: територіальну громаду; сільську, селищну, міську раду; сільського, селищного, міського голову; виконавчі органи сільської, селищної, міської ради; районні та обласні ради, що представляють спільні інтереси територіальних громад сіл, селищ, міст; органи самоорганізації населення [3].

Право на участь у місцевому самоврядуванні реалізується за належністю до відповідних територіальних громад; у сучасних умовах зростає значення цих первинних суб'єктів місцевого самоврядування. Бо тільки безпосередньо людина, 
спільноти (колективи), об'єднані спільними системно-комплексними інтересами і спільною територією проживання, спроможні чітко сформулювати, вирішити чи запропонувати оптимальні та ефективні способи розв'язання проблем місцевого значення.

Звідси, Закон України «Про місцеве самоврядування в Україні», який під територіальною громадою розуміє сукупність жителів, об'єднаних постійним проживанням у межах села, селища, міста, що є самостійними адміністративнотериторіальними одиницями, або добровільне об'єднання жителів кількох сіл, що мають єдиний адміністративний центр (ст. 1), фактично моделює і закріплює не тільки первинного суб'єкта місцевого самоврядування, основного носія його функцій і повноважень, а і основного суб'єкта-об'єкта муніципальної правової політики та ії основного бенефіціара.

Отже, територіальна громада - що, по великому рахунку, представляє собою історично обгрунтовану та функціонально-апробовану нормативно-правову модель самоорганізації населення 3 управлінськими структурами, здатними реалізувати і захищати місцеві інтереси $є$ об'єктивним продуцентом таких інтересів, що, безумовно повинні знайти своє відображення в профільній політиці і свою реалізацію в діяльності органів місцевого самоврядування.

Загалом, територіальна громада - це складна форма соціальної організації, автономна і самоврядна соціальна система, яку складає сукупність місцевих жителів, об'єднаних на публічних засадах у межах певної території. Такі добровільні об'єднання людей-жителів існують, діють та функціонують на підставі статуту або за рішенням місцевих референдумів об'єднуються 3 іншими громадами 3 метою здійснення самоврядування в межах конституції та законів держави. Їх наділено конкретною правосуб' єктністю, а саме:

- правом формування відповідних органів через проведення виборів, загальних зборів громадян за місцем проживання;

- правом проведення місцевих референдумів, місцевих ініціатив, громадських слухань, індивідуальних і колективних звернень, громадських експертиз та обговорень, інших не заборонених конституцією форм місцевої демократії;

- правом управління місцевими бюджетами, рухомим і нерухомим майном комунальної власності;

- правом укладати міжнародні угоди профільної спрямованості тощо [4, с. 4653].

Формами опосередкованої реалізації ними свого права на місцеве самоврядування є органи та посадові особи місцевого самоврядування, відповідні асоціації (спілки) місцевих влад тощо.

Виокремлюючи таку категорію суб'єктів, як адміністративно-територіальні одиниці (АТО), зазначимо, що вони є суб'єктами правовідносин і мають свій статус. Основою територіального утворення як відособленої складової частини території держави, в якій функціонують відповідні органи публічної влади, є певна територія i населення, що мешкає на цій території,- територіальна громада (частина населення держави).

Саме в контексті муніципальної реформи, що проводиться, а також в контексті формування муніципальної правової політики держави, спираючись на це, можна вирізнити такі елементи правового статусу територіальних утворень: соціальне призначення; компетенція (функції та повноваження); порядок формування (спосіб 
легітимізації), зміни і ліквідація; чітко визначені адміністративно-територіальні межі; внутрішня організація (організація влади, іiї взаємовідносини з центральною владою та іншими територіальними утвореннями); відповідальність. Зміст цих елементів у їх взаємозв'язку дозволяє визначити місце і роль територіальних утворень у системі територіальної організації держав, а також у процесі їхньої міжнародної співпраці та співробітництва з найактуальніших питань місцевого та регіонального розвитку.

Важливе місце в формуванні та реалізації муніципальної правової політики належить містам, які містять на своїх територіях великі територіальні спільноти. Складовими елементами правового статусу міста, зокрема, визначають: правосуб'єктність міста, його функції та компетенцію міської влади, механізм здійснення функцій міста і повноважень міської влади, гарантії їх реалізації, юридичну відповідальність міської влади [5, с. 5-7]. Це - пов'язані між собою і взаємодоповнювальні елементи. Сутність правового статусу міста розкривається в механізмі врегульованих нормами права соціальних відносин міста 3 людиною, державою, органами державної влади, органами і посадовими особами місцевого самоврядування, неурядовими організаціями, з іноземними суб'єктами та світовим співтовариством у цілому. Правосуб'єктність міста визначається як сукупність юридичних можливостей міста в особі територіальної громади, органів і посадових осіб бути учасником правовідносин, які виникають у процесі виконання ним своїх функцій за конституцією, законами і статутом громади. Отже, вважаємо, що наведені параметральні ознаки міського самоврядування також повинні стати об'єктами регулювання муніципальної правової політики.

Особливостями державної муніципальної політики, яка формується з позицій демократичного управління, $є$ законодавчо визначений офіційний статус об'єднань органів місцевого самоврядування як представників інтересів їх членів. Правовою основою для об'єднань органів місцевого самоврядування, як суб'єктів державної муніципальної політики став Закон України "Про асоціації органів місцевого самоврядування" від 16 квітня 2009 р. [6]. Цей нормативний акт також свідчив про формування неокорпоративної моделі представництва інтересів, яка орієнтована на обмежену кількість асоціацій, офіційно визнаних державою, як суб'єктів, що мають монопольне право представляти та формулювати інтереси певних зацікавлених груп.

Взаємодія об'єднань місцевого самоврядування з органами державної влади, міжнародними організаціями та установами визначає ще один важливий аспект їх політичної ролі. На відміну від органів місцевого самоврядування, які контролюються деякими повноваженнями, делегованими державою, їх добровільні об'єднання повністю незалежні (в організаційно-правовому сенсі) від державної форми реалізації територіальними громадами своїх інтересів.

Використовуючи форму асоційованої діяльності, органи самоврядування значно розширюють свої можливості виконуючи різноманітні соціально-економічні та квазіполітичні функції, включаючи презентацію нових соціальних потреб, що виникають внаслідок соціально-технічного прогресу та змін у соціальноекономічних умовах життя; здійснення контролю над державою, забезпечення прозорості та відкритості державних рішень [7, с.23].

Отже, діяльність добровільних об'єднань органів місцевого самоврядування як суб'єктів державної муніципальної політики $є$ одним із проявів та форм 
організаційної самостійності органів місцевого самоврядування у реалізації парадигми регіонального інтересу. Ця незалежність гарантується Конституцією України, Європейською хартією місцевого самоврядування, законами України "Про місцеве самоврядування в Україні" та "Про асоціації органів місцевого самоврядування".

Висновки. Виходячи з вищевикладеного, можна констатувати, що перехід до формування муніципальної правової політики вимагає кардинального перегляду всієї ідеології місцевого самоврядування, технологій управління, практики прийняття рішень та розподілу ресурсів. Це означає перехід: від підпорядкування до розуміння; від пасивної до активної участі територіальних громад у вирішенні місцевих проблем; від закритих до відкритих форм діяльності органів місцевого самоврядування; від соціально-корпоративного до нормативно-правового змісту прийняття рішень, чіткого регулювання ординарного муніципального процесу та процедур; від розподілу матеріальних та фінансових ресурсів до збільшення цих ресурсів за допомогою стратегічного планування та управління; від мобілізації використання ресурсів до запланованого типу їх примноження та розвитку; від окремого вирішення питань функціонування та розвитку - до їх спільного та узгодженого досягнення.

\section{Список використаних джерел:}

1. Конституція України: прийнята на п' ятій сесії Верховної Ради України 28 червня 1996 року. Відомості Верховної Ради Украйни. 1996. № 30. Ст. 141.

2. Камінська Н. В. Місцеве самоврядування: теоретико-історичний i порівняльно-правовий аналіз : навч. посіб. Київ : КНТ, 2010. 232 с.

3. Про місцеве самоврядування в Україні : Закон України від 21 травня 1997 року. Відомості Верховної Ради України. 1997. № 24. Ст. 170.

4. Прієшкіна О. В. Правове регулювання безпосередньої демократії в місцевому самоврядуванні України : дис. ... канд. юрид. наук. Одеса, 2002. 198 с.

5. Шкабаро В. М. Конституційно-правовий статус міста в Україні : автореф. дис. ... канд. юрид. наук. Київ, 2004. 21 с.

6. Про асоціації органів місцевого самоврядування : Закон України від 16 квітня 2009 року. Відомості Верховної Ради України. 2009. № 38. Ст. 534.

7. Батанов О. В. Тенденції розвитку муніципального права в умовах глобалізації. Вісник Південного регіонального цуентру Національної академї̈ правових наук України. 2016. № 9. С. 22-30.

\section{References:}

1. Konstytutsiia Ukrainy 1996 [Constitution of Ukraine 1996] (Verkhovna Rada Ukrainy) [(Verkhovna Rada of Ukraine)]. Vidomosti Verkhovnoi Rady Ukrainy [Information of the Verkhovna Rada of Ukraine], 30, 141. [in Ukrainian].

2. Kaminska, N. V. (2010). Mistseve samovriaduvannia: teoretyko-istorychnyi $i$ porionialno-pravovyi analiz: navchalnyi posibnyk [Local self-government: theoreticalhistorical and comparative-legal analysis: a textbook]. Kyiv: KNT. [in Ukrainian].

3. Zakon pro mistseve samovriaduvannia v Ukraini 1997 [Law on Local SelfGovernment in Ukraine of 1997] (Verkhovna Rada Ukrainy) [(Verkhovna Rada of Ukraine)]. Vidomosti Verkhovnoi Rady Ukrainy [Information of the Verkhovna Rada of Ukraine], 24, 170. [in Ukrainian]. 
4. Priieshkina, O. V. (2002). Pravove rehuliuvannia bezposerednoi demokratii v mistsevomu samovriaduvanni Ukrainy: dysertatsiia kandydata yurydychnykh nauk [Legal regulation of direct democracy in local self-government of Ukraine: the dissertation of the candidate of legal sciences]. Odesa. [in Ukrainian].

5. Shkabaro, V. M. (2004). Konstytutsiino-pravovyi status mista v Ukraini: avtoreferat dysertatsii kandydata yurydychnykh nauk [Constitutional and legal status of the city in Ukraine: abstract of the dissertation of the candidate of legal sciences]. Kyiv. [in Ukrainian].

6. Zakon pro asotsiatsii orhaniv mistsevoho samovriaduvannia 2009 [Law on Associations of Local Self - Government Bodies] (Verkhovna Rada Ukrainy) [(Verkhovna Rada of Ukraine)]. Vidomosti Verkhovnoi Rady Ukrainy [Information of the Verkhovna Rada of Ukraine], 38, 534. [in Ukrainian].

7. Batanov, O. V. (2016). Tendentsii rozvytku munitsypalnoho prava v umovakh hlobalizatsii [Trends in the development of municipal law in the context of globalization]. Visnyk Pivdennoho rehionalnoho tsentru Natsionalnoi akademii pravovykh nauk Ukrainy [Bulletin of the Southern Regional Center of the National Academy of Legal Sciences of Ukraine], no. 9, 22-30. [in Ukrainian]. 